Session 2426

\title{
Development of a Temperature Control System Laboratory and Design Module for an Introduction to Engineering Design Course
}

\author{
Sven G. Bilén, Elizabeth C. Kisenwether, and Andrew S. Lau \\ Engineering Design and Graphics Division \\ The Pennsylvania State University \\ University Park, PA 16802
}

\begin{abstract}
We have developed a half-semester design module that exposes first-year students to the engineering design process by directing them through the development of a temperature control system. The module is used at Penn State in ED\&G 100: Introduction to Engineering Design and is often the first exposure that students have with engineering processes and the engineering laboratory environment. The design module is highly relevant in that sensors and control systems are prevalent in many engineering fields. We employ a constructivist approach by starting with basic concepts, following with hands-on experiments, reflecting on what was learned, and making connections between theory and application. The module uses modern test equipment in an engineering laboratory environment.
\end{abstract}

\section{Introduction}

Engineering education has seen many initiatives over the last decade. Gradually, engineering educators have come to realize the improved learning that comes from hands-on, student-centered, team-based experiences, especially in the first year. ${ }^{1}$ While there are excellent pedagogical reasons for many of these initiatives, there is also an increasing influence of the ABET Engineering Criteria 2000. ${ }^{2}$ Of course, one expects that the ABET 2000 criteria are essentially a reflection of the pedagogical developments.

Put in ABET EC 2000 context, the laboratory and design module described here addresses at least these six ABET Criteria (letters correspond to the ABET Criteria):

a. An ability to apply knowledge of mathematics, science, and engineering;

b. An ability to design and conduct experiments, as well as to analyze and interpret data;

c. An ability to design a system, component, or process to meet desired needs;

d. An ability to function on multi-disciplinary teams;

e. An ability to identify, formulate, and solve engineering problems;

g. An ability to communicate effectively.

This is perhaps the special nature of this module - it addresses so many of the desired outcomes. 
The fundamental pedagogical principle employed in this course module is that of constructivist learning. This principle originated in developmental psychology, found application in K-12 education - especially science education - and has now made its way to engineering education. ${ }^{3}$ Constructivist learning theory states that knowledge is actively constructed by the mind of the learner through experiences. ${ }^{4,5}$ Constructivism suggests: (a) the learner should be an active organism within the environment, not just responding to stimuli, but engaging and seeking to make sense of things; (b) knowledge is best generated internally, not absorbed from an external source; and (c) the motivation for learning should be intrinsic. ${ }^{2}$ The discovery process is enhanced by repeated, prolonged experiences with the materials and events associated with the topic to be learned.

As Lyons et al. ${ }^{3}$ point out, another important concept from constructivism is that of scaffolding, which is the process of guiding the learner from what is presently known to what is to be known. It is not uncommon for both students and faculty to feel that first-year engineering students are incapable of doing engineering. After all, they have not yet had their college math and science courses, or any engineering courses. Yet they do have significant knowledge from their K-12 educations and from their life experiences. Scaffolding recognizes the skills and abilities that students have, and allows students to perform beyond these abilities with appropriate support from the teacher and the instructional materials.

The typical sequence employed by faculty teaching ED\&G100: Introduction to Engineering Design at Penn State is a half-semester structured design module followed by a less structured, but more in-depth, industry-sponsored design experience. The first design module ${ }^{6}$ that we have developed is what will be discussed in this paper. The module is titled Designing $a$ temperature control system using a Basic Stamp II Microcontroller: An introduction to the design process and laboratory techniques for Engineering Design \& Graphics 100. In this paper, we first give an overview of the module and the objective for each lab of the module. We next discuss the development of the lab resulting from student feedback that was solicited. Finally, we make some summary comments about module.

\section{Overview of Lab Experiments and Objectives}

In the design module that we have developed, students design a temperature control system by moving through a series of labs that teaches them various principles and components that they must integrate in the final lab. The design module is divided into four sections, or labs, that can be completed in six two-hour sessions. After some introductory material and exercises, the first lab includes experiments on simple electrical circuits in which students test basic circuit properties such as Ohm's and Kirchhoff's Laws and become familiar with resistors and LEDs. (see Table 1 for a listing and description of all topics.) The second lab exposes students to the concept of binary numbers and how an analog-to-digital converter (ADC) converts real-world signals into a form that a microcontroller can understand. In this section a simple voltmeter is built by attaching a potentiometer functioning as a voltage divider to the ADC, which itself is connected to a BASIC Stamp II, a modern, inexpensive microcontroller that can be programmed in BASIC. ${ }^{7}$ (Table 2) The third lab has the students work with a thermistor as a sensor that measures temperature and has the students collect resistance versus temperature data, from which is developed an equation to calculate temperature from resistance value. (Table 3) The final lab, for which students are given two sessions to complete, has the students put all the 
pieces together to develop a system to control the temperature in a small enclosed area by using the thermistor as a sensor and a power resistor as a heater. This last exercise also introduces students to the concept of heat transfer and introduces them to power supplies and relays used in the heater circuit. (Table 4)

Tables 1-4 list the specific topics covered in each lab. There are several items that are part of each lab in addition to these specific topics. The labs are set up such that the objectives are listed first so that the students are prepared for what they are to learn in the lab. Although the equipment they will need is generally prepared ahead of time for them, a listing of all new equipment is made so students know what is needed in the lab. Figure 1 shows a picture of the material required for this design module. A "For Next Time" section ties what they have learned in the current lab to what will be learned in the following lab. Finally, some "Notes Pages" are provided for students to take lab notes and to paste in items such as plots and program listings, and to draw complete circuits. The importance of developing good laboratory note-taking techniques is emphasized and hints are given as to the type of material that should be included.

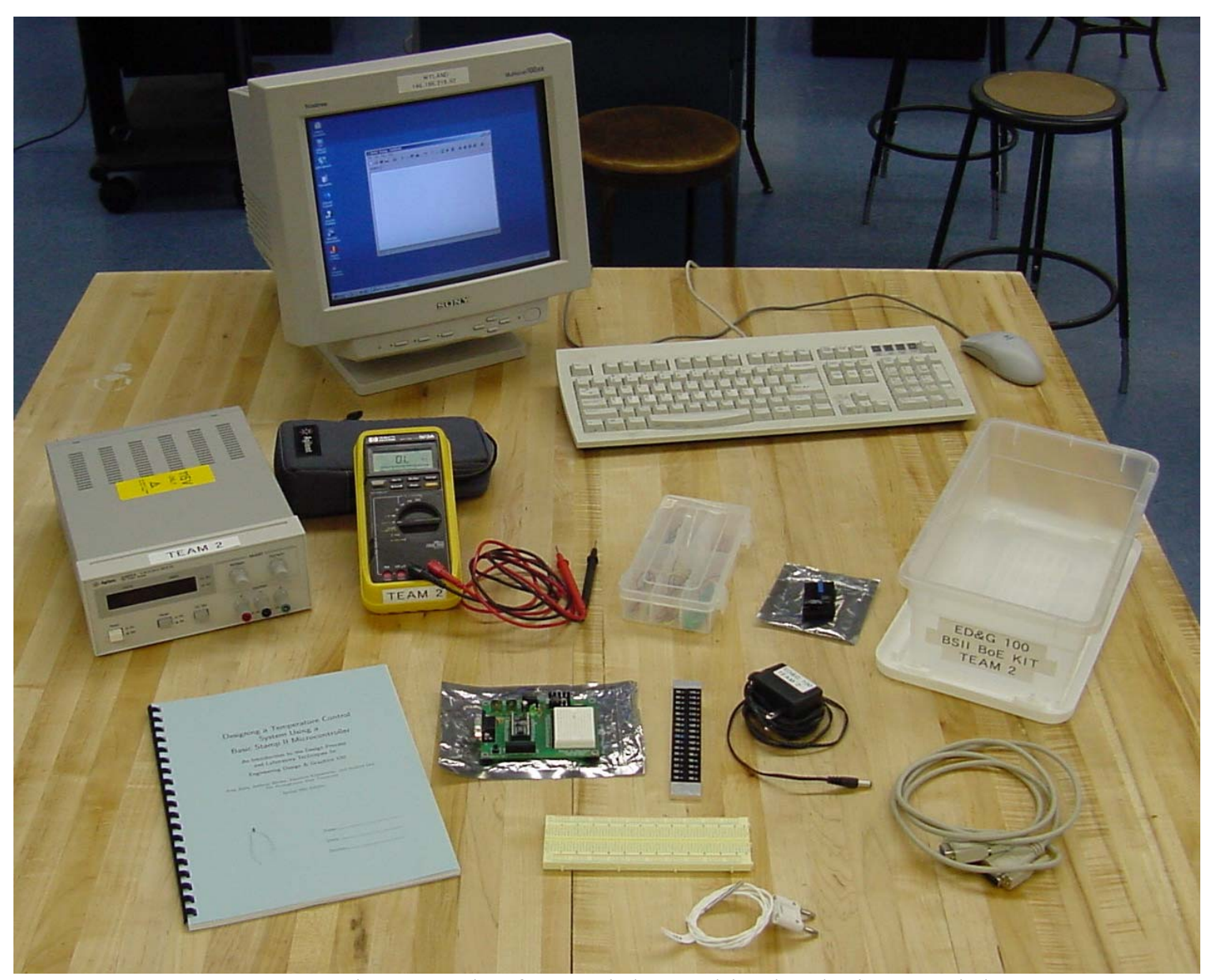

Figure 1 Photograph of materials used in the design module. 
Table 1 Listing of topics covered in the Introduction and Lab 1

\begin{tabular}{|c|c|c|}
\hline $\begin{array}{r}\text { Lab } \\
\text { Section }\end{array}$ & Section Title & Section Objectives and Comments \\
\hline Intro. & Introduction & $\begin{array}{l}\text { Provides an introduction to the first lab module and places } \\
\text { it into the context of the EDG } 100 \text { course. In response to } \\
\text { student misperceptions, an exercise was added having the } \\
\text { students research sensors that might be employed in their } \\
\text { expected majors. Students are asked to place their chosen } \\
\text { sensors into control systems. }\end{array}$ \\
\hline Lab 1 & Signals and Circuits & \\
\hline 1.2 & Foundations of Electricity & \\
\hline 1.2 .1 & $\begin{array}{l}\text { Voltage, current, and resistance-Ohm's } \\
\text { Law }\end{array}$ & $\begin{array}{l}\text { Presents the concepts of voltage, current, resistance and the } \\
\text { relationship between them as Ohm's Law. Also presents } \\
\text { the concept of power. }\end{array}$ \\
\hline 1.2 .2 & Beyond the basics-resistor networks & Series and parallel resistor networks \\
\hline 1.2 .3 & $\begin{array}{l}\text { What is that resistor's resistance?- } \\
\text { Resistor color code }\end{array}$ & How to read resistor color codes and discusses tolerance \\
\hline 1.2 .4 & The circuit breadboard & $\begin{array}{l}\text { How breadboards work and how to hook together } \\
\text { components }\end{array}$ \\
\hline 1.3 & Exploring the Basics & \\
\hline 1.3 .3 & Step 1-DMM familiarization & $\begin{array}{l}\text { Familiarizes the students with the operations of a handheld } \\
\text { digital multimeter (DMM) }\end{array}$ \\
\hline 1.3 .4 & Step 2-Resistors & $\begin{array}{l}\text { Students measure single resistors and series and parallel } \\
\text { resistors with the DMM and compare to calculated values }\end{array}$ \\
\hline 1.3 .5 & Step 3-Kirchhoff's Voltage Law & $\begin{array}{l}\text { Students measure voltage drops in a simple series circuit } \\
\text { with the DMM and verify KVL. Presents the concept of a } \\
\text { voltage divider. }\end{array}$ \\
\hline 1.3 .6 & Step 4-Kirchhoff's Current Law & $\begin{array}{l}\text { Students measure currents in a parallel circuit with the } \\
\text { DMM and verify KCL }\end{array}$ \\
\hline 1.3 .7 & $\begin{array}{l}\text { Step 5-Going beyond resistors: the } \\
\text { LED }\end{array}$ & $\begin{array}{l}\text { Presents the light emitting diode (LED) as a new circuit } \\
\text { component that does not obey Ohm's Law }\end{array}$ \\
\hline
\end{tabular}


Table 2 Listing of topics covered in Lab 2

\begin{tabular}{|c|c|c|}
\hline $\begin{array}{r}\text { Lab } \\
\text { Section }\end{array}$ & Section Title & Section Objectives and Comments \\
\hline$\angle a b 2$ & Binary Numbers and the Basic Stamp II & \\
\hline 2.2 & Different Numbers, Same Meaning & $\begin{array}{l}\text { Presents the concept of binary numbers and how to covert } \\
\text { to/from decimal }\end{array}$ \\
\hline 2.3 & $\begin{array}{l}\text { Real World to Digital Domain-A/D } \\
\text { Converters }\end{array}$ & $\begin{array}{l}\text { Introduces the analog-to-digital converter (ADC) and the } \\
\text { difference between analog and discrete domains }\end{array}$ \\
\hline 2.4 & The Basic Stamp II & \\
\hline 2.5 & Procedure 1—BSII LED Demo & $\begin{array}{l}\text { Presents the students with a simple design problem of } \\
\text { blinking on and off a pair of LEDs }\end{array}$ \\
\hline 2.5 .1 & Step 1-Startup & Starting the coding program \\
\hline 2.5 .2 & Step 2-Writing BASIC code & $\begin{array}{l}\text { Presents a simple piece of code to perform the blinking } \\
\text { LED function }\end{array}$ \\
\hline 2.5 .3 & Step 3-Our demo LED circuit & Wiring up the LED to the BSII \\
\hline 2.5 .4 & Step 4-Upload to the BSII & Uploading the code and running it \\
\hline 2.5 .5 & Step 5-Observations & $\begin{array}{l}\text { Analyze the operation of the simple computer driven } \\
\text { circuit }\end{array}$ \\
\hline 2.6 & Procedure 2-The Potentiometer & \\
\hline 2.6 .1 & $\begin{array}{l}\text { Step 1-Potentiometer resistance } \\
\text { measurements }\end{array}$ & $\begin{array}{l}\text { Students measure the resistances of the two halves of a } \\
\text { potentiometer and compare to the total value for various } \\
\text { positions of the wiper }\end{array}$ \\
\hline 2.6 .2 & $\begin{array}{l}\text { Step 2-The potentiometer as a voltage } \\
\text { divider }\end{array}$ & $\begin{array}{l}\text { Students determine that a potentiometer is really a voltage } \\
\text { divider }\end{array}$ \\
\hline 2.7 & $\begin{array}{l}\text { Procedure 3-The ADC and the Real } \\
\text { World }\end{array}$ & \\
\hline 2.7 .1 & Step $1-$ DC voltmeter & $\begin{array}{l}\text { Students construct a simple voltmeter with a potentiometer } \\
\text { and the ADC chip hooked up to the BSII }\end{array}$ \\
\hline 2.7 .2 & Step 2-BSII with ADC & $\begin{array}{l}\text { Students load a prewritten program to output binary } \\
\text { voltage measurements }\end{array}$ \\
\hline 2.7 .3 & $\begin{array}{l}\text { Step 3-ADC with binary to decimal } \\
\text { conversion }\end{array}$ & $\begin{array}{l}\text { Students load a second program that converts the binary } \\
\text { output to decimal }\end{array}$ \\
\hline 2.7 .4 & Step 4-Quantization & $\begin{array}{l}\text { Students explore the concept of quantization and manually } \\
\text { covert decimal numbers to voltage }\end{array}$ \\
\hline 2.7 .5 & Step 4-Having the BSII do the work & $\begin{array}{l}\text { Students load a third program that performs the } \\
\text { conversions for them and outputs voltage values }(0-5 \mathrm{~V})\end{array}$ \\
\hline
\end{tabular}


Table 3 Listing of topics covered in Lab 3

\begin{tabular}{rll}
\hline \hline $\begin{array}{r}\text { Lab } \\
\text { Section }\end{array}$ & Section Title & Section Objectives and Comments \\
\hline \hline Lab 3 & Sensing Temperature with a Thermistor & \\
\hline \hline 3.2 & Task: Control Temperature & $\begin{array}{l}\text { Presents the problem of designing a system to control } \\
\text { temperature in a "product MJ12," which is a film container }\end{array}$ \\
\hline 3.3 & Problem Analysis & $\begin{array}{l}\text { Students are to work out a plan of attack: what is the } \\
\text { control system they would use; class discussion shows } \\
\text { students what others have come up with }\end{array}$ \\
\hline 3.3 .1 & Individual/class discussion & $\begin{array}{l}\text { Presents the thermistor as a transducer that converts } \\
\text { temperature to a resistance }\end{array}$ \\
\hline 3.4 & Measuring Temperature & $\begin{array}{l}\text { Students measure the thermistor's value at room } \\
\text { temperature }\end{array}$ \\
\hline 3.4 .4 & $\begin{array}{l}\text { Step 2-Measuring the thermistor's } \\
\text { nominal resistance } R\left(T_{0}\right)\end{array}$ & $\begin{array}{l}\text { Students measure resistance as a function of temperature, } \\
\text { and temperature as a function of time for an aluminum } \\
\text { block }\end{array}$ \\
\hline 3.4 .5 & $\begin{array}{l}\text { Step 3-Measuring the thermistor } \\
\text { resistance-temperature characteristic }\end{array}$ & $\begin{array}{l}\text { Students use Excel to determine a linear curve fit to their } \\
\text { collected resistance vs. temperature data }\end{array}$ \\
\hline 3.4 .6 & $\begin{array}{l}\text { Step 4-Finding the thermistor } \\
\text { calibration curve }\end{array}$ & $\begin{array}{l}\text { Students explore higher-order functions that fit the data } \\
\text { better and explore the tradeoffs of using these curve fits }\end{array}$ \\
\hline 3.4 .7 & Step 5-A better model for $R_{T}(T)$ & $\begin{array}{l}\text { Students plot temperature vs. time data and determine the } \\
\text { thermal time constant of the aluminum bar }\end{array}$ \\
\hline 3.4 .8 & Step 6-Thermal time constants
\end{tabular}


Table 4 Listing of topics covered in Lab 4

\begin{tabular}{|c|c|c|}
\hline $\begin{array}{r}\text { Lab } \\
\text { Section }\end{array}$ & Section Title & Section Objectives and Comments \\
\hline $2 \mathrm{Lab} 4$ & Temperature Control Design Project & \\
\hline 4.2 & Exploring Heat Transfer & $\begin{array}{l}\text { Students first make some qualitative observations about } \\
\text { the container in which they are to control the temperature }\end{array}$ \\
\hline 4.2 .1 & Heat transfer background & $\begin{array}{l}\text { Background material on heat transfer making analogy } \\
\text { between thermal resistance and electrical resistance and } \\
\text { series thermal circuits }\end{array}$ \\
\hline 4.2 .2 & Finding thermal resistances & $\begin{array}{l}\text { Presents thermal resistances for some common materials } \\
\text { and has students work through an example of a series } \\
\text { thermal circuit }\end{array}$ \\
\hline 4.2 .3 & Sizing the heater & $\begin{array}{l}\text { Student design an experiment to determine the overall heat } \\
\text { transfer equation for their film canister and determine the } \\
\text { size heater needed }\end{array}$ \\
\hline 4.3 & Designing a Temperature Control System & \\
\hline 4.3 .3 & $\begin{array}{l}\text { Step } 1-\text { Measurement of thermistor } \\
\text { resistance }\end{array}$ & $\begin{array}{l}\text { Uses the principle of a voltage divider with thermistor as } \\
\text { bottom leg for input to the ADC }\end{array}$ \\
\hline 4.3.4 & Step 2-Measurement of temperature & $\begin{array}{l}\text { Students code in the linear thermistor equation they found } \\
\text { previously and have BSII circuit measure temperature }\end{array}$ \\
\hline 4.3 .5 & Step 3-Heating the MJ12 & $\begin{array}{l}\text { Students determine a heater size and attach it to their BSII } \\
\text { circuit via a relay and use an external power supply }\end{array}$ \\
\hline 4.3 .6 & $\begin{array}{l}\text { Step 4-A first attempt at temperature } \\
\text { control }\end{array}$ & $\begin{array}{l}\text { Students use a mostly prewritten program to operate their } \\
\text { control system, but they must determine some subroutines }\end{array}$ \\
\hline 4.3 .7 & $\begin{array}{l}\text { Step 5-Completing the temperature } \\
\text { controller }\end{array}$ & The design is completed to meet required specifications \\
\hline 4.3 .8 & $\begin{array}{l}\text { Step 6-Design evaluation and } \\
\text { observations }\end{array}$ & $\begin{array}{l}\text { Design is evaluated for meeting performance } \\
\text { specifications and what additional items could affect } \\
\text { performance }\end{array}$ \\
\hline 4.3 .9 & Step 7-A final task and verification & $\begin{array}{l}\text { The DMM thermistor is used to verify that their system is } \\
\text { controlling to within required specifications; the thermal } \\
\text { time constant of the container is found and compared to } \\
\text { the aluminum bar }\end{array}$ \\
\hline
\end{tabular}

\section{Lab Development}

We discuss here some of the student perceptions of this design module and how the need to address those perceptions has guided its development. One of the misperceptions many students had in the first version of the module was that it was relevant only to electrical engineering because of the use of circuits and a microcontroller in the control system. To address this misperception, we begin by having students research sensor technologies used by practitioners in their anticipated field of engineering (mechanical, civil, chemical, electrical, etc.). Students see that the principles of sensors and data collection apply to all fields of engineering. We have also developed additional content related to heat transfer and the design of the heating circuit.

A questionnaire given to all the BASIC Stamp II Design Lab students at the conclusion of the Lab provided valuable insights into how to improve the BSII Lab. The second version of the project incorporated many of the students' suggestions. Example questions and student 
replies are discussed here, with responses and changes made to support improved problem-based learning.

Please let us know what prior experience you had (if any) in: (a) microcomputer (like a BASIC Stamp) skills; (b) team lab work? This first question was used to gauge the background the students had before starting the module. We found the background in programming to be fairly mixed, as well as team lab work.

What material in the design module did you find to be completely new (first time they had seen it)? We asked this question (presented in checklist form) and found most indicated the use of breadboard, digital multimeter (DMM), power supply, power calculations, potentiometers, relay switch, thermistor, BASIC Stamp II, and the BASIC coding language. Many had previously been exposed to KVL and KCL in high-school physics but appreciated the refresher. It was clear from the comments that even those high school students in the collegeprep "tracks" in high school had few opportunities to use the DMM. Many students had built the basic light bulb-switch-battery circuits, but few had actually used a DMM to measure voltage, current, resistance.

What part of the BSII Design Lab did you find most challenging? Students found three features of the BSII Lab challenging - and none of the items related directly to the electronics or sensors work in the lab. First, students found the logistics of a team of four students working with a small breadboard (measuring 4 inches by 6 inches) around a large lab bench a logistical challenge. Wiring connections made on the BSII Board and the accompanying prototype board are on 0.1-in. spacing, and the components are all less than 2 inches in length, so not every student could see exactly what connections were being made in the circuit fabrication and measurements. This was a source of confusion, delay, and frustration. The solution suggested by the instructors was to pause at the end of each task and have all team members look again at the circuit and ask any and all questions needed to understand the circuit and measured results. This step also reinforced the learning process and knowledge to be gained. Second, students saw and experienced the "dominant student" syndrome, where the student with experience (even minimal) in circuit design or measurements became the team leader, often doing much of the circuit assembly and measurements. The solution was to make an announcement in class to "stop work," and have the team rotate the location of the BSII Board to the team member that's been working with the BSII Board the least. This invariably forces the team to backtrack on the work and explain to all team members the current circuit design and what is being measured or constructed. Finally, students commented that because the BSII Lab was held only once per week, they could not remember where they left off from the previous Lab. The solution as to add more notes pages to the BSII lab manual, and to strongly encourage all team members to make sketches and schematics of the circuit design and layout. Instructors found that halting work approximately 10 minutes before the end of class and encouraging this documentation step was important. Students learned that design documentation is critical, and can save significant time and confusion.

What can be supplied for the BSII lab to make it more time-efficient? To minimize costs, only a total of 10 of BSII Boards were purchased. Eight BSII Boards were used in each lab session by the eight teams, with two spare boards. In addition, only 10 prototype boards (sized $4 " \times 6{ }^{\prime \prime}$ ) were provided, so each team had one BSII Board and one prototype board set. 
Four teams in the four sections shared these BSII Lab sets, which meant that the circuits were "torn down" after each lab session in order to reuse the BSII Board and prototype board. After only one semester teaching the BSII Lab, it became clear students wanted to keep their circuit designs intact as much as possible between labs: significant time was lost each lab period in rebuilding the circuits. Thus, each individual team should have a prototype board of their own (full set of components for building all the BSII Lab tasks).

\section{What sensors should we have available to use with the BSII in the final design} project? The BSII Lab is focused on the use of the thermistor to measure temperature in a small chamber, and driving the temperature inside the chamber with a heating resistor. The control loop is simple - with voltage applied to the heating resistor to increase temperature up to $102^{\circ} \mathrm{F}$, then shutting off the voltage, and letting the chamber cool by ambient heat dissipation. Two sensors could be added to the lab to increase the complexity (and add more opportunities for experimentation and design.) First, a small cooling fan could be added, forcing outside air over the heating chamber for faster cooling. Speed of the fan could also be controlled, rather than having the binary "on/off" control scheme. Second, another thermistor could be placed outside the chamber, either against the plastic chamber wall, or some distance away. This data could be used in the heat transfer equations, and used to match theory to experimental data.

\section{Summary}

The half-semester design module that we have developed exposes first-year students to the engineering design process by directing them through the development of a temperature control system. A constructivist approach is used by starting with basic concepts, following with hands-on experiments, reflecting on what was learned, and making connections between theory and application. Although students initially feel that they do not have enough knowledge in such areas as basic circuits, sensors, and microcontrollers to complete the project, they invariably have a sense of accomplishment at having progressed successfully through learning the new principles and the engineering design process.

\section{Acknowledgments}

The authors would like to thank Dr. Robert Pangborn, Associate Dean for Undergraduate Studies, for funding the development of this lab module; Anthony Skraba for helping define the initial version of the module; and Agilent Technologies for donated test equipment used in this lab.

\section{References}

1. Simon, H. (1998), "What We Know About Learning," Journal of Engineering Education, v. 87, n. 4, p 343.

2. ABET Engineering Criteria 2000, http://www.abet.org, 2000.

3. Lyons, J., J. Morehouse, and E. Young, Design of a Laboratory to Teach Design of Experiments, Proceedings of the American Society for Engineering Education Annual Conference, Session 2566, Albuquerque NM, June 24-July 27, 2001.

4. Piaget, J. (1973), To understand is to invent. New York: Grossman.

5. Vygotsky, L. (1978), Mind in Society: The Development of Higher Psychological Processes MA: Harvard University Press. 
6. Bilén, S., A. Skraba, E. Kisenwether, and A. Lau, Designing a temperature control system using a Basic Stamp II Microcontroller: An introduction to the design process and laboratory techniques for Engineering Design \& Graphics 100, Spring 2002 edition.

7. Parallax, Inc., Basic Stamp Programming Manual, Version 1.9, 1998.

SVEN G. BILÉN (BS Penn State, MSE and PhD Univ. of Michigan) is an Assistant Professor of Engineering Design and Electrical Engineering. His educational research interests include developing techniques for enhancing engineering design education and teaching technological entrepreneurship. He is member of IEEE, AIAA, AGU, ASEE, URSI, and Sigma Xi.

ELIZABETH (LIZ) C. KISENWETHER (BSEE Penn State, MSEE MIT, MSEE Johns Hopkins) is an Assistant Professor in the College of Engineering and Project Director for the Problem-Based Learning in Entrepreneurship Program. Her teaching emphasis is engineering design (first year and senior capstone courses) and engineering entrepreneurship. Prior to joining Penn State in 1999, Liz worked for 11 years in the defense industry and five years at a start-up company specializing in video-to-flat panel and video decompression products. She is the founder and president of the non-profit corporation KidTech, doing K-12 engineering education kit design and outreach.

ANDREW S. LAU is an Associate Professor of Engineering Design and Graphics and Coordinator of First-Year Seminars for the College of Engineering at Penn State. Prof. Lau has B.S.M.E. from Penn State and an M.S.M.E. from the University of Wisconsin-Madison. His areas of interest include green design, solar energy applications, modeling of building energy use, and student-centered learning. 